\title{
津波によるライフライン被害に関する 調查的研究
}

\author{
宮島 昌克 1 藤間 功司 2 庄司 学 3 ・鴫原 良典 4 \\ 1正会員 金沢大学教授 理工研究域環境デザイン学系（テ920-1192 石川県金沢市角間町） \\ E-mail:miyajima@t。kanazawa-u。ac。jp \\ 3 正会員 防衛大学校教授 システム工学群建設環境工学科（テ239-8686 神奈川県横須賀市走水1-10-20） \\ E-mail: fujima@nda。ac。jp。 \\ 2 正会員 筑波大学大学院准教授 システム情報工学研究科（テ305-8573 茨城県つくば市天王台1-1-1） \\ E-mail: gshoji@kz。tsukuba。ac。jp \\ 3 正会員 防衛大学校助教 システム工学群建設環境工学科（テ239-8686 神奈川県横須賀市走水1-10-20）
}

E-mail: shigi@nda。ac。jp。

\begin{abstract}
本論文は，津波によるライフライン被害について検討したものである。今世紀中ごろまでに東南海・南 海地震が発生するのではないかと言われており，この地震により紀伊半島から四国沿岸に至る広範囲にお いて津波が来襲することが危惧されている。まず, 津波によるライフライン被害の特徵を過去の被害事例 から明らかにする必要があるが，近年，日本国内で津波によりライフラインが被害を受けた事例はほとん ど見当たらない。そこで，浸水被害という点では多くの共通点を有すると考えられる，日本国内における 高波，高潮によるライフライン被害事例に着目して被害の特徴を明らかにした。さらに，2009年9月にサ モア諸島南方沖を震源とする地震において津波被害を蒙った米領サモアのライフライン被害について現地 調査結果を基に考察した。最後に，津波被害の特徵と対応策について考究した。
\end{abstract}

Key Words : lifeline, tsunami, flood tide, high wave, damage,2009 South of Samoa Islands earthquake,

\section{1.はじめに}

2004年12月にインドネシアのスマトラ島沖で発 生した地震による大津波 ${ }^{1)}$ では, インドネシアのみ ならずインド洋沿岸各国に甚大な被害を与え，犠牲 者数は約 23 万人にも上った。この津波において，家 屋，橋梁，道路などの構造物に甚大な被害が発生し, 人的被害の大きな要因となった。一方で, 海岸地域 のライフライン施設も大きな被害を受け，被災後の 早期復旧，復興に甚大な影響を及ぼした。わが国で は，今世紀中ごろまでに東南海・南海地震が発生す るのではないかと言われており，この地震により紀 伊半島から四国沿岸に至る広範囲において津波が来 襲することが危惧されている。このような地震は, 1944年東南海地震, 1946年南海地震以来であるが, 当時と社会基盤構造物が様変わりしているので，当 時の被害状況から来るべき地震の被害を予測するこ とは容易なことではない。また, 近年, 日本国内で 津波によりライフラインが被害を受けた事例は, 1993年北海道南西地震による奥尻島の電力施設被害
以外に殆ど見当たらない。

そこで本研究では，まず，浸水被害という点で 多くの共通点を有すると考えられる日本国内におけ る高波，高潮によるライフライン被害事例に着目し， 被害の特徵を明らかにする。つぎに，2009年9月に サモア諸島南方沖を震源とする地震において津波被 害を蒙った米領サモアのライフライン被害について 現地調査結果を基に考察する。最後に, 津波被害の 特徴と対策について考究する。

\section{2. わが国における高波, 高潮によるライフラ イン被害事例}

近年，日本国内で津波によりライフラインが被害 を受けた事例は，1993年北海道南西地震による奥尻 島の電力施設被害以外に殆ど見当たらないので，浸 水被害という点では多くの共通点を有すると考えら れる, 日本国内における高波, 高潮によるライフラ イン被害事例に着目した。本論文では，平成3年台 風19号と平成11年台風18号による高潮被害を受けた 
山口県の周南流域下水道浄化センターと, 平成16年 台風18号による高波被害を受けた鹿児島県沖永良部 島の知名環境センターの被害事例について検討する。

\section{(1) 周南流域下水道浄化センターの高潮被害}

平成3年台風19号により高潮による越波が発生し, 護岸の崩壊により浄化センター場内に海水が浸水し, 管理棟地下の電気設備, 各地下管廊, スカム棟, 沈 砂池地下の機械・電気設備など全ての地下構造物が 海水に浸ることにより被害を受けた。護岸の被災範 囲は $317 \mathrm{~m}$ 及んだ。この被害により，竣工当時 $8.50 \mathrm{~m}$ であった堤防高さを $9.25 \mathrm{~m}$ 嵩上げした。

平成 11 年台風 18 号による高潮では，嵩上げした堤 防を越えるよりも，堤防で囲まれた浄化センターを 回りみ，堤防高さよりも低くなっていた道路を伝っ て陸側にある正門から一気に水が流れ込んで冠水し た。この結果, 最大 $1.8 \mathrm{~m}$ 程度の場内冠水 (写真-1) と なり，地下は完全に水没した。

このような度重なる被害を経験して, 以下のよう な対策が講じられている。

- 護岸からの越波対策として既往最大潮位DL+5.5 $\mathrm{m}$ に対し, D. L. +6. 33mの異常潮位が発生した余 裕を見てD. L. $+8.8 \mathrm{~m}$ を目標水位とした高上げを 行う。

- 場内浸水時の排水を促進するための放流口を設 け，排水口には海水の逆流を防止するためのフ ラップゲートを設ける。

- 場内各施設には，冠水時の施設への流入を防止 するための扉の防水化, 防水扉の設置, 開口部 の嵩上げや閉塞などを行う。

- 電気設備や機械設備の浸水防止のため, 堤防高 さまでの設置レベルの嵩上げ, 設置フロアの地 下から階上への変更を行う。

\section{（2）知名環境センターの高波被害}

平成16年台風18号による高波および暴風による海 水の浸水，飛沫により施設が海水を浴びた。約 $90 \mathrm{~cm}$ (D. L. $+10.20 \mathrm{~m}$ ) 冠水したので機械・電気設備など 全ての地下構造物が浸水し, 取替えを余儀なくされ た。被災後の対策としては, D. L. $+10.40 \mathrm{~m}$ までの堤 防の嵩上げが行われた(写真-2)のみである。前述し た，周南流域下水道浄化センターのように，波が超 えない施設とするだけではなく, 万が一入ってきた 海水を許容できる施設, 例えば地下施設覆蓋, 機 械・電気設備の上部移設, 防水扉などの対応も検討 する必要があると考えられる。

\section{2009年サモア諸島沖地震津波による米領サ モアのライフライン被害}

2009年9月 29 日午前6時48分（現地時間）に発生し たサモア諸島南方（南緯15.3度, 西経171.0度）を 震源とする地震によって津波が発生し, サモア諸島 に大きな被害を及ぼした。著者らは，同年11月8日 〜15日に特に津波被害が大きかった米領サモアを対 象に, 津波の浸水高, 遡上高の調査と, ライフライ

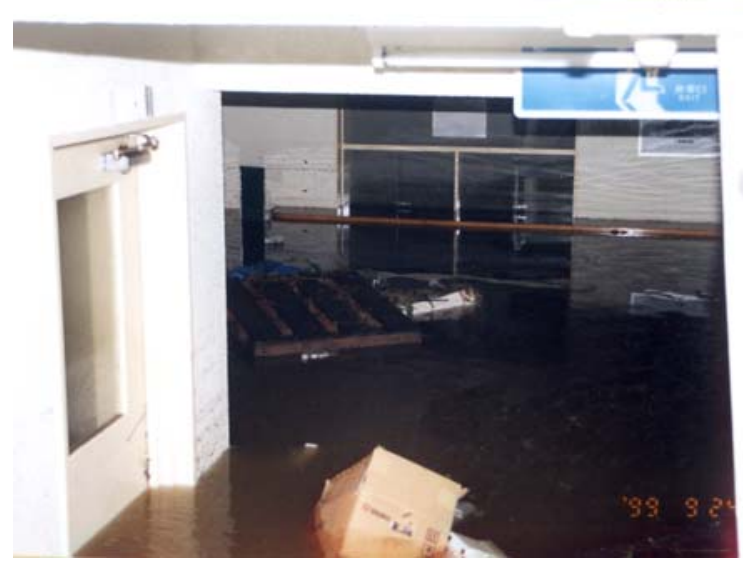

写真-1 場内冠水の様子 (周南流域下水道浄化センター提供)

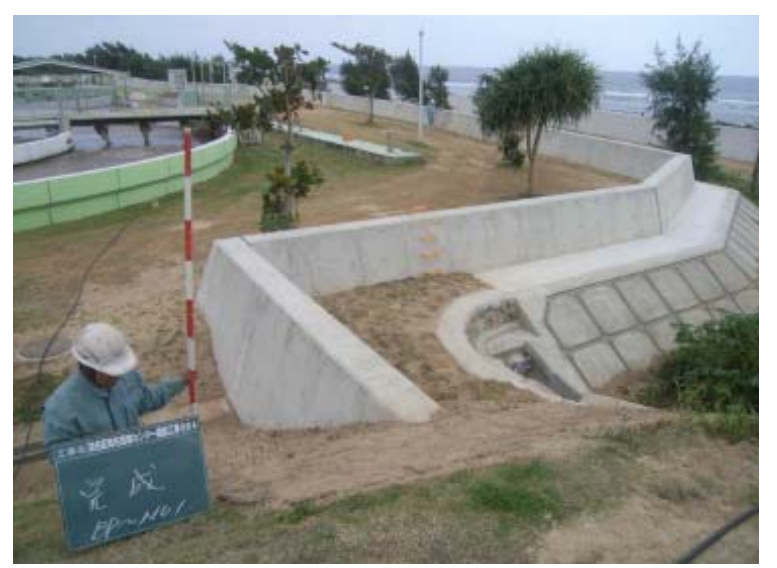

写真-2 被災後の堤防の嵩上げ (知名環境センター提供)

ン施設の被害について現地調査を行った。米領サモ アはサモア諸島の西経171度以東に属する7島からな っており, 総人口は約 7 万人でる。そのうちの約 80\%が居住する最も大きな島がTuTuila島である。 地図を図-1に示す。

なお，米領サモアの電力および上下水道はASPA

(American Samoa Power Authority) によって管理, 運営されており, 本稿はASPAにおけるヒアリングに 基づいている。

\section{（1）地震，津波および被害の概要}

2009年9月29日午前6時48分（現地時間）に発生し た地震のマグニチュードはUSGSによればMW 8.0であ り，太平洋津波警報センター (PTWC) によればMW 8.3 である。震源はサモア独立国の首都Apiaから $190 \mathrm{~km}$, ニュージーランドのAucklandからは2, 700km離れた 深さ $18 \mathrm{~km}$ 地点である。

この地震で発生した津波の浸水高, 遡上高さをラ イフラインが整備されている島の南側において計測 した。計測結果を図ー2に示す。津波高さは西側で 高くなる計呼応があり, 最大で $10 \mathrm{~m}$ 以上の浸水高, 遡上高であった。また, 島の東端でも大きな浸水高 であった。この理由については海底地形などの情報 


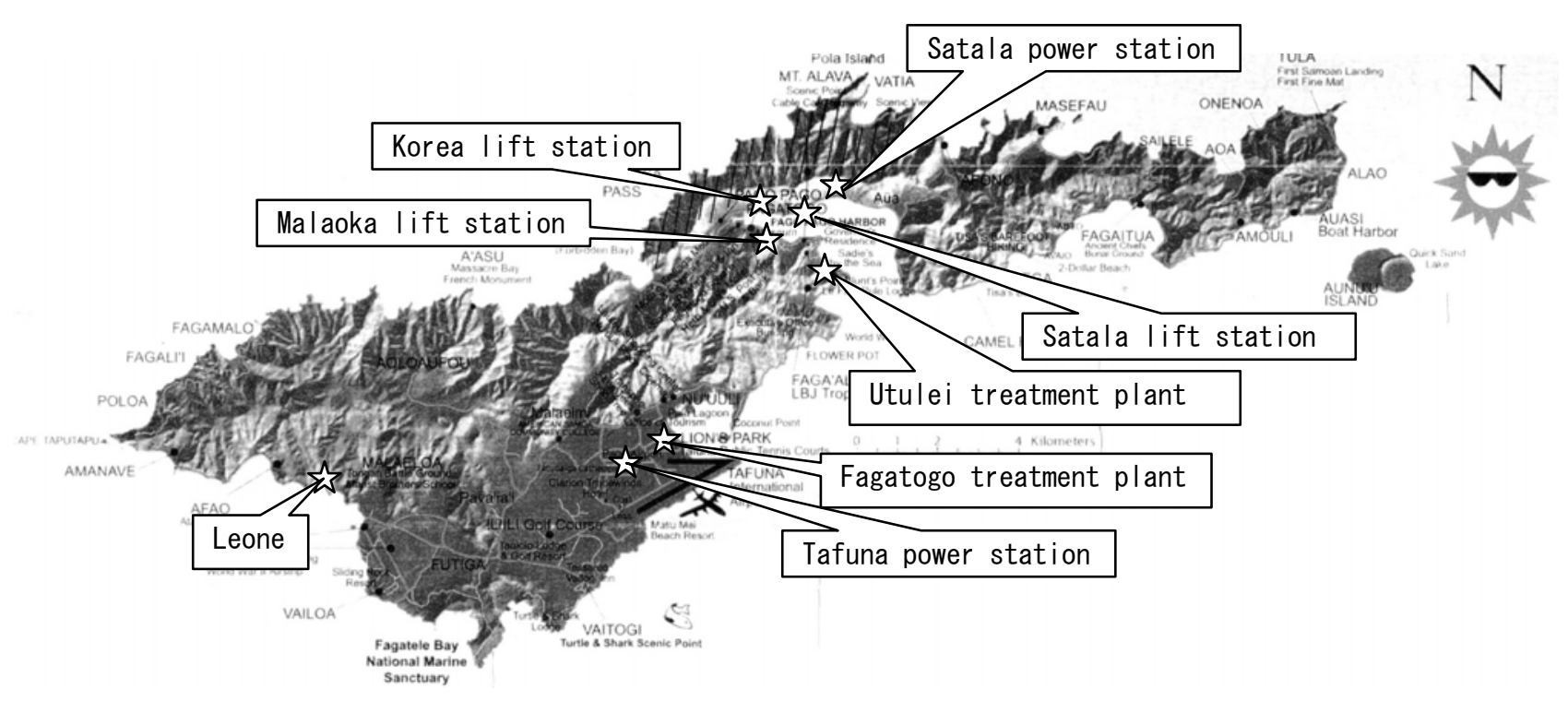

図-1 米領サモア TuTuila 島の地図と主な施設名

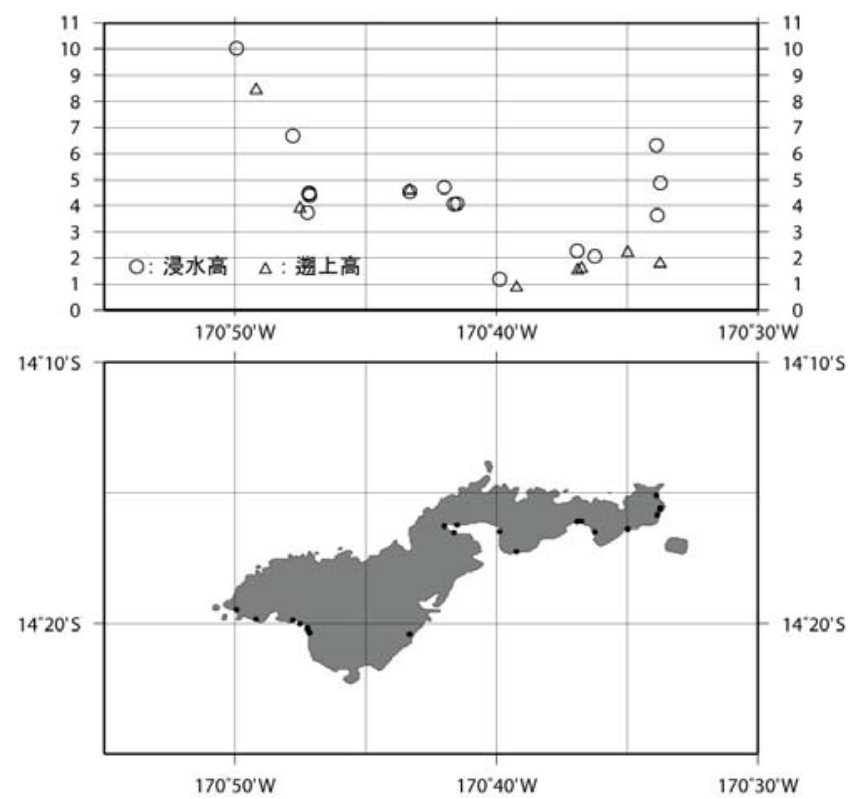

図-2＼cjkstart浸水高と遡上高さの計測結果

をさらに収集して検討する必要がある。

USGSによれば, 震度はApiaで V, 米領サモアの Iliili，TafunaでVIであった（いずれもMM震度階）。 気象庁震度階では震度 III から IVに相当する。著者ら が行った住民へのヒアリングによれば，一部で食器 が転落した程度で家具の転倒や移動は見られなかっ たということであるので, 気象庁震度階でIV程度で はないかと推測される。しかし，後述するように上 水道の石綿セメント管が破損し, 漏水したり, 家屋 の鉄筋コンクリート梁に小さな亀裂が入った所もあ るので, 場所によっては震度 $\mathrm{V}$ 弱相当の地域もあっ たものと推測される。今回の地震津波による犠牲者 はUSGSによると, サモア独立国で149名，米領サモ アで34名，トンガで9名の192名となっている。

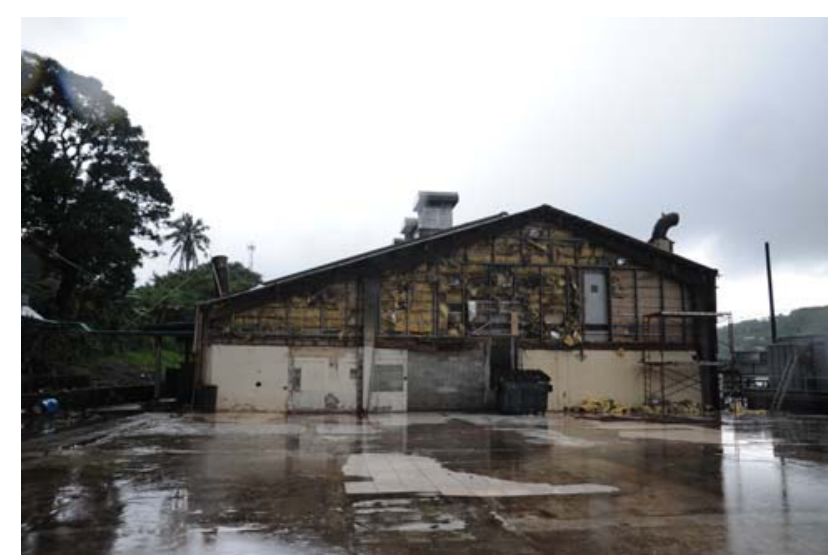

写真-3＼cjkstart津波被害を受けた Satala 発電所

\section{（2）電力施設の被害}

Tutuila島の西部に電力を供給しているTafuna発 電所と東部に供給しているSatala発電所がある。い ずれも火力発電所である。Tafuna発電所は海岸から 離れていたので津波の襲来を受けなかったが, Satala発電所はPago Pago湾北部に海岸線を走る道 路を挟んで立地していたので，津波の襲来を直接受 けることになった。

写真-3はSatala発電所の外観を示しているが，手 前の空間は発電所の管理棟があったところで，木造 だったために津波によって建物全体が押し流された とのことである。発電所本体は鉄筋コンクリートの 柱, 梁とブロック造の壁からなっており, 建物の構 造部材には大きな損傷は見られなかった。発電所の 内部は写真-4に示すとおりであり，発電所の建物背 面に浸水高の痕跡が残っていたので(写真-5), 海水 面からの高さを計測すると潮位補正後の浸水高は $4.1 \mathrm{~m}$ (地盤面から $2.04 \mathrm{~m})$ であった。

Satala発電所が津波により機能停止に陥ったので, Tutuila島の東部への電力供給が完全にストップし た。ASPAでは手持ちの発電機やニュージーランドか 
ら急遽発電機をレンタルして急場をしのぎ, 3 日後 には停電は一応解消した。地震 2 週間後にFEMAが大 型の $500 \mathrm{kw}$ 発電機を 10 機持ち込み，要所に配置した ので，ようやく通常に近い状況になったとのことで ある。地震後 1 ケ月上経った, 本調查時点でも状 況は変わっておらず, FEMA (Federal Emergency Management Agency)の持ち込んだ大型発電機が活躍 していた。

FEMAは災害による被害額の査定や, 復旧費の助成 も行っており, Satala発電所においては，標高の高 い別の地域に移転して新築するか，現在の場所なら ば嵩上げをした後に新築する場合に限って復旧費を 補助するとしているとのことであった。

\section{（3）上水道施設の被害}

米領サモアの上水道は2箇所で河川水を水源とし, それぞれの浄水場を有するとともに，56の井戸も水 源となっている。配水管の総延長は約 $190 \mathrm{~km}$ であり, 約 9,000 世帯に 9 つの配水ブロックにより供給してい る。配水管の口径は2/3インチ〜24インチ（16mm〜 $610 \mathrm{~mm}$ ）であり，管種はポリ塩化ビニル管が主であ り, 石綿セメント管, ダクタイル鉄管, 鋼管も使わ れている。給水管にはポリエチレン管が使われてい るとのことであった。

津波による直接的な被害としてはLeoneにおける 橋梁添架管の被害が挙げられる。津波による洗掘に より 2 径間のコンクリート橋の橋台 1 基が転倒し, 1 径間が倒壊することにより, 添架されていた12イン チの鋼管が切断された。この管路はTutuila島西部 に水を供給する配水幹線だったので，この被害によ り Leoneより西の地域はすべて断水した。倒壊した 1 径間を土砂で埋めることにより道路を仮復旧し,

それとともに破断箇所にポリ塩化ビニル管をつない で仮復旧した（写真-6）。影響の重大さから突貫工 事を行った結果, 地震翌日の午前 3 時には通水が再 開できたようである。著者らの計測によればLeone での浸水高は約 $3.7 \mathrm{~m}$ (地盤面から $1.30 \mathrm{~m}$ ) だった。

Fagatogoでは, 岸壁の一部が洗掘により洗い流さ れ，16インチのポリ塩化ビニル管の埋設土も流され， 管路が露出し，鉛直，水平方向にそれぞれ約 $30 \mathrm{~cm}$ 移 動したが, 漏水など管路の損傷は生じなかった。

前述したようにSatala発電所からの電力供給の停 止により, 島の東部にある16箇所の上水道のポンプ 場も停止し，影響を受けた。ASPAが事前に準備して いた発電機や，急遽ニュージーランドから借り受け たもの, FEMAが持ち込んだものなどにより対応して いる。

津波の被害が大きかった地域では，津波により家 屋に大きな被害が生じるとともに，水道メーターや 3/4インチの給水管も被害を受け, 取替えや修繥が 行われた。

一方，地震そのものによる管路被害も生じていた。 主として石綿セメント管であるが16インチ管などに も被害が生じている。

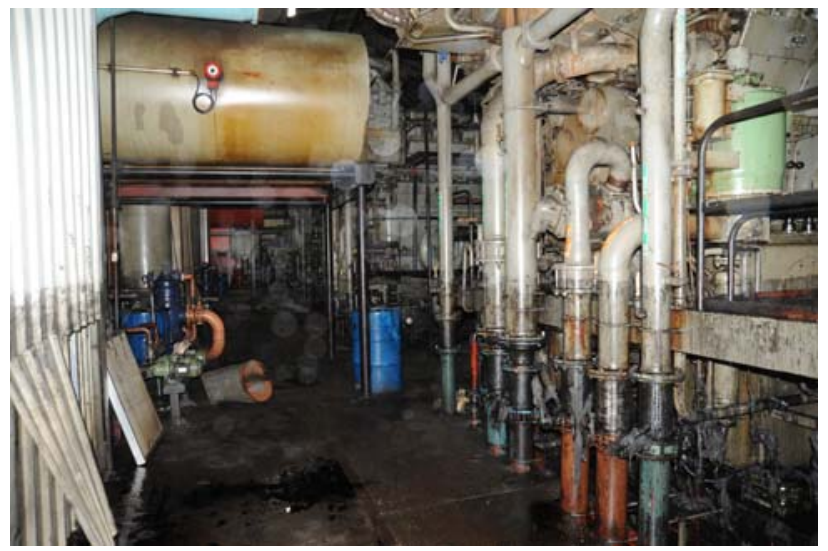

写真-4 津波を受けた Satala 発電所の内部

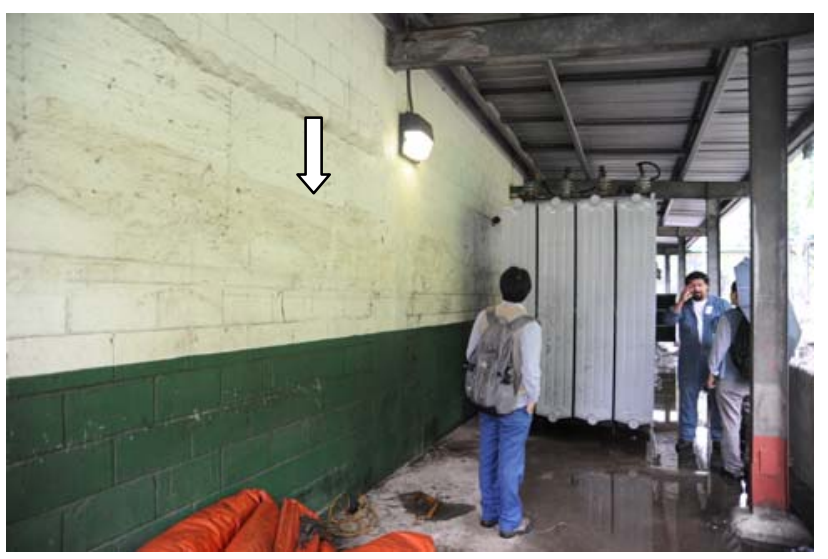

写真-5 Satala 発電所背面における津波浸水高 の痕跡

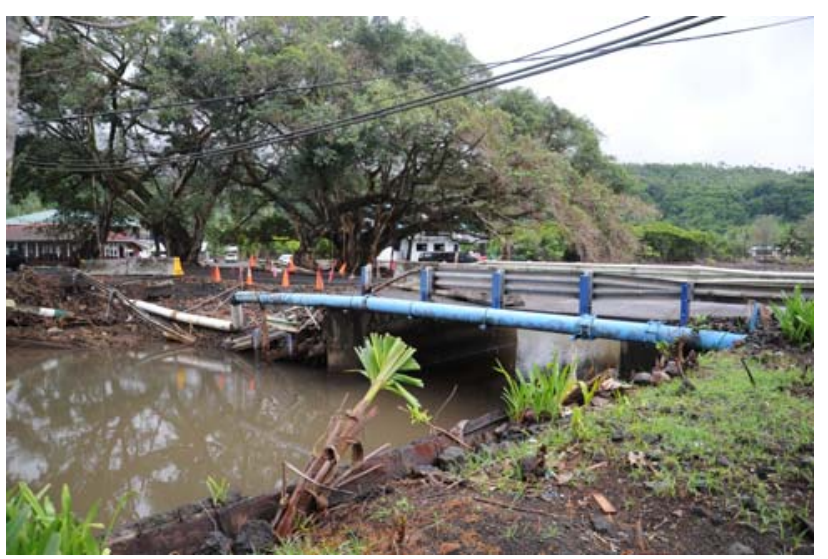

写真-6 Leone における橋梁添架管の仮復旧状況

\section{（4）下水道施設の被害}

下水道はTutuila島全体に整備されているわけで はなく, 中央部の西部と東部の 2 つの処理区があり， それぞれ終末処理場を有している。

西部処理区の終末処理場はFagatogoにあり, 津波 の来襲を受け, 海岸側に設置されていた岩の塀が破 壊された。従業員の証言を元に測量すると, 津波の 浸水高は海水面から $4.5 \mathrm{~m}$ (地盤面から $0.75 \mathrm{~m}$ ) となっ たが，幸いなことに処理場の建物内が浸水すること はなく, 津波後も稼動し続けることができた。 
東部処理区の終末処理場はUtuleiにあり，施設前 の道路までで津波は止まり，ここも被害を受けなか つた。ちなみに海水面から道路面までの高さは 2. $46 \mathrm{~m}$ であった。

下水道施設の主な施設被害はマンホールポンプが 津波により水没し，コントロールパネルが作動しな くなるというものだった。Pago Pago湾沿岸を含む 東部処理区には7つのマンホールポンプがあるが, このうち Malaoka lift station, Korea lift station, Satala lift stationの3つが津波により 水没し，作動しなくなった。なお， lift stationと は，自然流下で流れてきてマンホール内にたまった 下水を，高さを稼ぐためにマンホールポンプで高い 位置に移動させるが，マンホールポンプとそれを電 気的に制御するためのコントロールパネルの総称で ある。被災後の調査により，ポンプ自体は作動する が，水没したことによりコントロールパネルが作動 しなくなったことがわかったので，従業員が各マン ホールポンプに貼り付き, 手動でポンプのオン・オ フを行うことで対応した。

Si’ufagaにあるKorea lift stationの傍にある擁 壁のコケの色が津波により変色している境界 (写真7) を測量したところ, 海水面から $4.7 \mathrm{~m}$ (地盤面から 1.80m)であった。また, Malaoka lift stationでは 建物の屋根に津波の痕跡が認められたので，海水面 からの高さを測量すると潮位補正後の浸水高は4.1 m(地盤面から $3.00 \mathrm{~m})$ であった。

\section{（5）被害の特徵}

Pago Pago 湾北部の海岸近くに位置していた Satala発電所が，地盤から約 $2 \mathrm{~m} の$ 高さまで浸水し機 能停止に陥った。この被害により島の東側が全て停 電するとともに，上下水道の機能にも大きな影響を 与えた。米領サモアでは1917年以来大きな津波を経 験していないので津波に対する対策は皆無の状態で あった。また，津波の波力により管理棟が流出する という大きな被害に見舞われた。自明のことではあ るが, 電気の機能被害は他のライフラインの機能障 害に波及する特に重要なライフラインであるので, 海岸近くの施設には万が一の津波に対しても対策が 重要であることが改めて示されたといえる。

上水道施設では橋梁添架管の破断と洗掘による埋 土の流出が見られた。いずれも橋梁, 地盤の津波被 害に伴うものであるが，添架位置や埋設位置を工夫 するなどの対応も考えられる。

下水道施設ではマンホールポンプの制御盤の水没 による被害が生じた。海岸近くにある終末処理場は 幸いなことに水没を免れたが，津波対策が必要であ ることは言うまでもない。

現地調査では, 津波の浸水高, 遡上高を計測した が，多くのライフラインの地下施設は，浸水高に関 わらず，津波が遡上して水没した時点で機能停止に 陷るということも示された。

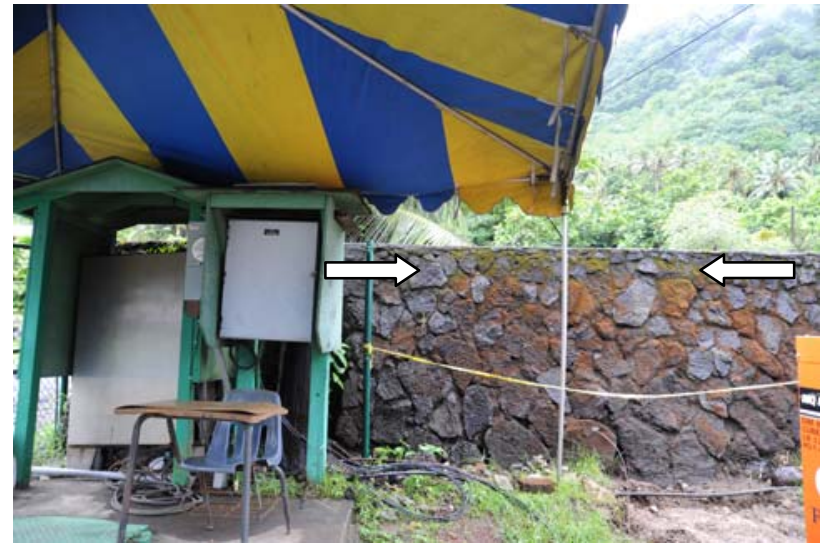

写真-7 津波による擁壁のコケの変色

(Korea lift station)

\section{4. 津波によるライフライン被害の特徴と対策}

津波そのものによるライフラインの構造被害は, 津波の波力そのものによる被害と浸水による被害に 大別される。波力そのものによる被害も, 米領サモ アで見られたSatala発電所の管理棟の流出のような 流体力そのものによる被害と, 洗掘に伴う橋台の転 倒や護岸の流出による橋梁添架管や埋設管の移動の ような，二次災害的なものに分けることができる。

一方，浸水による被害は，わが国の高波，高潮 被害の事例と共通する点が多く見られる。水没に伴 う機械・電気設備の被災が深刻であることが現地調 査から明らかとなった。海水を被ることになるので, 全ての機器の取替えが必要となり, 復旧に時間を要 することになる。大地震の際には，地震被害からの 早期復旧, 復興が急務の課題となるが, 機器の取替 えに時間を要していては，早期復旧，復興に甚大な 影響を及ぼす可能性がある。なお，浸水被害には海 水を被ることによる被害のほかに，浸水に伴う浮力 による被害が考えられる。サモアでは浮力のみの影 響による被害は見られなかったが，わが国では木造 の施設が少なくないのでこの点についても注意が必 要である。

サモアではライフラインの津波対策は皆無であ り，高潮，高波に対しても同様であった。サモアで の津波被害とわが国の高潮，高波対策から考えられ るライフラインの対策としては, 他の社会基盤構造 物と同様に，津波そのものを海岸線で防ぐための防 潮堤の整備, 嵩上げが基本であるが，想定以上の津 波が来襲した場合や河川を遡上した津波による浸水 も想定しなければならない場合もあると考えられる。 他のライフラインとの連関も考慮した重要度に応じ て，いくつかの想定レベル，対策レベルを設定して 対策することが望まれる。すなわち，他のライフラ インの機能被害に直接影響を及ぼす電気施設の場合 には，万が一浸水しても対応できる対策，すなわち 周南流域下水道浄化センターで見られたような, 地 
下施設覆蓋, 機械・電気設備の上部移設, 防水扉な ごの対策が考えられる。海岸線付近に建設されてい ることの多い火力発電所や下水道終末処理場, それ らの施設につながる共同溝やマンホールポンプなど については，早急な津波対策が望まれる。

\section{5. 結論}

本論文は，近年発生した日本国内における高波， 高潮によるライフライン被害事例に着目し, 被害の 特徵を明らかにするとともに，2009年9月にサモア 諸島南方沖を震源とする地震において津波被害を蒙 った米領サモアのライフライン被害について現地調 査結果を基に考察した。得られた結論は以下の通り である。

1）わが国の高波，高潮によるライフライン被害調 査より，堤防の高上げなどによる波が超えない 施設とするだけではなく，万が一入ってきた海 水を許容できる施設, 例えば地下施設覆蓋, 機 械・電気設備の上部移設, 防水屝などの対応が 重要であることが示された。

2）サモアの津波被害調査より，津波そのものによ るライフラインの構造被害を, 津波の波力その ものによる被害と浸水による被害に大別するこ とができると考えられた。さらに，浸水被害に は海水を被ることによる被害のほかに，浸水に 伴う浮力による被害も考慮する必要がある。

3）サモアの現地調查では，津波の浸水高，遡上高 を計測したが，多くのライフラインの地下施設 は，浸水高に関わらず，津波が遡上して水没し た時点で機能停止に陥るということが示された。 したがって，津波の遡上高の推定が重要である。

4） ライフラインの対策としては，他の社会基盤構 造物と同様に，津波そのものを海岸線で防ぐた めの防潮堤の整備，嵩上げが基本であるが，想 定以上の津波が来襲した場合や河川を遡上した 津波による浸水も想定しなければならない場合 もあると考えられる。他のライフラインとの連 関も考慮した重要度に応じて, いくつかの想定
レベル，対策レベルを設定して対策することが 望まれる。

津波から人命を守るためにはいち早い避難が唯一 の対策であるが，避難の後には早急な復興が望まれ る。地震および津波被害からの一日も早い復興のた めにはライフライン機能の回復が第一であり, その ためには基幹ライフラインの, その中でも最も重要 な施設の地震および津波対策が重要であることが, 米領サモアの被害調査結果から示された。ライフラ インの津波対策が，巨大地震対策の盲点となってい ないか検証することが急がされているといえる。

謝辞：国内における被害事例の調査は，土木学会地 震工学委員会「地下構造物の合理的な地震対策研究 小委員会」（委員長：大塚久哲九州大学教授）の第 3WGの活動として行われたものです。調査を一緒に 行っていただいた第3WG委員の皆様, 現地で懇切丁 寧なご説明と資料の提供を賜つた関係各位に謝意を 表します。また, 米領サモアの現地調査において被 害の概要から訪問先の紹介までご教示いただきまし たAmerican Samoa Community CollegeのDon Vargo 博士，ライフライン被害についての資料を提供して 下さいましたASPA の Water Manager の Ne'emia Mareko氏に深謝いたします。現地調査の準備に当た り有益な事前情報をいただきました, 秋田大学准教 授 高橋智幸先生に感謝いたします。最後になりま したが，現地調査において気軽にインタビューに答 えて頂いた住民の皆様に謝意を表すとともに，亡く なられた方々のご冥福をお祈りし，1日も早い復興 を祈念します。

\section{参考文献}

1）藤間功司，鴫原良典，Charles SHIMAMORA，松冨英夫， 榊山勉, 辰巳大介, 宮島昌克, 伯野元彦, 竹内幹雄, 小野祐輔, 幸左賢二, 庄司 学, 田崎賢治: スマトラ 北西海岸における2004年インド洋津波の痕跡高分布, 土木学会地震工学論文集, Vol. 29, pp. 876-880, 2007. 8.

（原稿受理2010年7月23日）

\section{INVESTIGATIVE STUDY ON DAMAGE TO LIFELINE FACILITIES SUBJECTED BY TSUNAMI}

\section{Masakatsu MIYAJIMA, Koji FUJIMA, Gaku SHOJI and Yoshinori SHIGIHARA}

The paper focuses on damage to lifeline facilities subjected to Tsunami. Tsunami will hit the wide areas between Kii peninsula and the coast of Shikoku if the Tohnankai and Tohkai Earthquakes happen. The precedents of damage to lifeline in the recent earthquakes do not exist because the large tsunami did not occur in the recent earthquakes around Japan. We firstly focus on the damage to lifeline facilities due to flood tide and high wave occurred in Japan and clarify the characteristics of the damage by flood. Then the damage caused by the 2009 South of Samoa Islands Earthquake and tsunami is investigated through reconnaissance work. Finally we study the characteristics of damage to lifeline facilities subjected to tsunami and its counter measures. 